\title{
Size-segregated compositional analysis of aerosol particles collected in the European Arctic during the ACCACIA campaign
}

\author{
G. Young ${ }^{1, *}$, H. M. Jones ${ }^{1}$, E. Darbyshire ${ }^{1}$, K. J. Baustian ${ }^{2}$, J. B. McQuaid ${ }^{2}$, K. N. Bower ${ }^{1}$, P. J. Connolly ${ }^{1}$, \\ M. W. Gallagher ${ }^{1}$, and T. W. Choularton ${ }^{1}$ \\ ${ }^{1}$ Centre for Atmospheric Science, University of Manchester, Manchester, UK \\ ${ }^{2}$ School of Earth and Environment, University of Leeds, Leeds, UK \\ * Invited contribution by G. Young, recipient of the EGU Outstanding Student Poster (OSP) Award 2015.
}

Correspondence to: G. Young (gillian.young@manchester.ac.uk)

Received: 9 October 2015 - Published in Atmos. Chem. Phys. Discuss.: 29 October 2015

Revised: 10 February 2016 - Accepted: 8 March 2016 - Published: 29 March 2016

\begin{abstract}
Single-particle compositional analysis of filter samples collected on board the Facility for Airborne Atmospheric Measurements (FAAM) BAe-146 aircraft is presented for six flights during the springtime Aerosol-Cloud Coupling and Climate Interactions in the Arctic (ACCACIA) campaign (March-April 2013). Scanning electron microscopy was utilised to derive size-segregated particle compositions and size distributions, and these were compared to corresponding data from wing-mounted optical particle counters. Reasonable agreement between the calculated number size distributions was found. Significant variability in composition was observed, with differing external and internal mixing identified, between air mass trajectory cases based on HYbrid Single-Particle Lagrangian Integrated Trajectory (HYSPLIT) analyses. Dominant particle classes were silicate-based dusts and sea salts, with particles notably rich in $\mathrm{K}$ and $\mathrm{Ca}$ detected in one case. Source regions varied from the Arctic Ocean and Greenland through to northern Russia and the European continent. Good agreement between the back trajectories was mirrored by comparable compositional trends between samples. Silicate dusts were identified in all cases, and the elemental composition of the dust was consistent for all samples except one. It is hypothesised that long-range, high-altitude transport was primarily responsible for this dust, with likely sources including the Asian arid regions.
\end{abstract}

\section{Introduction}

The response of the Arctic environment to climate change has received increased interest in recent years due to the visible loss in sea-ice volume over the past 3 decades (e.g. Serreze et al., 2007; Perovich et al., 2008). The polar regions of our planet have a unique response to a warming atmosphere due to environmental characteristics vastly different to the mid-latitudes, including high surface albedo and strong variability in annual solar radiation. These factors cause the Arctic to respond to climatic changes at a heightened pace (Curry et al., 1996). The complexity of the Arctic environment requires detailed observations to further our understanding of the feedbacks and underlying processes involved; however, the ability to carry out such studies is hampered by the remote location, which is difficult for in situ investigation.

Existing numerical models do not effectively reproduce the changing Arctic environment. Discrepancies in forecasted sea-ice coverage, and predicted dates for $100 \%$ loss, are due to a variety of uncertainties within the models themselves (e.g. de Boer et al., 2014). A key uncertainty in our ability to model how these changes will progress is in our representation of atmospheric aerosol-cloud interactions (Boucher et al., 2013). Aerosols play an important role in the Arctic radiative balance and their influence is thought to be amplified by the unique environmental conditions of this region (Quinn et al., 2007). The annual cycle of aerosol concentration in the Arctic varies significantly by season - with highs in spring of approximately 4-5 times that observed in late summer (Heintzenberg et al., 1986) - and such variabil- 
ity impacts the microphysics of the mixed-phase clouds commonly observed (Verlinde et al., 2007).

The interaction of aerosol particles with clouds as ice nucleating particles (INPs) or cloud condensation nuclei (CCN) is dependent upon properties such as their size, hygroscopicity and composition (Pruppacher and Klett, 1997). Aerosol particles can therefore influence ice crystal or cloud droplet number, thus affecting properties such as droplet effective radius or cloud optical depth (Zhao et al., 2012); properties which significantly affect the net radiative impact of the cloud (Curry et al., 1996). The study of INPs has developed significantly in recent years via laboratory and field studies (DeMott et al., 2010; Hoose and Möhler, 2012). It is still not clear which properties of aerosol particles promote them to act as INPs in the atmosphere. They are generally thought to be insoluble, super-micron in size, have a similar molecular structure to ice (Pruppacher and Klett, 1997) and have the potential to produce chemical bonds with ice molecules at their surface (Murray et al., 2012). For example, mineral dusts are known INPs and are used regularly in laboratory studies of ice nucleation (e.g. Zimmermann et al., 2008; Connolly et al., 2009; Kanji et al., 2013; Yakobi-Hancock et al., 2013). Sources of these particles are not ubiquitous across the globe. Internally mixed particles can also act as INPs or (giant) CCN. A complex particle is difficult to clearly categorise as an INP or CCN as its nucleation will be heavily dependent on the environmental conditions. The presence of coatings on particles can also have a significant impact on their role in aerosol-cloud interactions. Coatings of soluble material could enhance $\mathrm{CCN}$ ability and promote secondary ice production via the formation of large cloud drops (Levin et al., 1996), whilst organic coatings could suppress the nucleating ability of an efficient INP (Möhler et al., 2008). It is not well understood which particles, in which mixing state and from which sources facilitate ice nucleation in the Arctic atmosphere.

Previous studies of Arctic aerosol have indicated that the population is primarily composed of organic material, continental pollutants (e.g. as sulfate or nitrate gases), crustal minerals and locally sourced species such as sea salt (Barrie, 1986; Hara et al., 2003; Behrenfeldt et al., 2008; Geng et al., 2010; Weinbruch et al., 2012). A wide range of sources contribute to this population and it is difficult to quantify the impact of different regions. Extended studies of Arctic aerosol have been conducted, which consider the differences in particle properties between seasons, showing that the annual cycle of aerosol particle composition (Ström et al., 2003; Weinbruch et al., 2012) and concentration (Ström et al., 2003; Tunved et al., 2013) is dominated by the influence of the Arctic haze (Barrie, 1986; Shaw, 1995). Between February and April, an influx of aerosol from anthropogenic sources becomes trapped in the stable Arctic atmosphere and persists for long periods of time (up to several weeks) before being removed by precipitation processes (Shaw, 1995). Spring in the European Arctic is routinely characterised by these high particle number concentrations, dominated by the accumulation mode, and low precipitation rates with comparison to summer, autumn and winter (Tunved et al., 2013). During this time, aerosol particles have the potential to interact with other species, grow and develop with a low chance of being removed from the atmosphere. This promotes an enhanced state of mixing (e.g. Hara et al., 2003), which compounds the difficulty in understanding how these particles interact with the clouds in the region. It is thought that the European continent is the primary source of this aerosol, with only small contributions from North America and Asia (Rahn, 1981); however, long-range transport from the Asian continent has been found to sporadically contribute to this phenomenon (Liu et al., 2015). Improving our understanding of the properties of these aerosol particles will help us to comprehend how they influence the clouds of the Arctic, and a strong method of achieving this is by identifying their chemical composition (Andreae and Rosenfeld, 2008).

By improving our knowledge of aerosol and cloud properties via in situ observational studies in the Arctic, it is possible to reduce the uncertainty associated with aerosol-cloud interactions (Vihma et al., 2014). To this end, the AerosolCloud Coupling and Climate Interactions in the Arctic (ACCACIA) campaign was carried out in the European Arctic in 2013, utilising airborne- and ship-based measurements to collect a detailed data set of the Arctic atmosphere. The campaign was split into spring and summer segments, completed in March-April and July of 2013 respectively. During the spring section of the campaign, the Facility for Airborne Atmospheric Measurements (FAAM) BAe-146 atmospheric research aircraft was flown in the vicinity of Svalbard, Norway, with the capability of collecting in situ samples of aerosol particles on filters. This study presents the analysis of filter samples collected during this campaign, with a focus placed upon identifying the compositional properties and sources of the non-volatile, coarse-mode aerosol particles present in the atmosphere during the Arctic spring and inferring how these might interact with the cloud microphysics in the region.

\section{Campaign overview}

The springtime ACCACIA campaign flights were mainly conducted to the south-east of Svalbard, with the exception of flight B768, which was carried out to the north-west near the boundary with Greenland. Figure 1 details the science sections of each of the flights of interest, with direction from Svalbard to Kiruna, Sweden in all cases except B765. Corresponding dates are listed in Table 1.

As part of the springtime campaign, $47 \mathrm{~mm}$ diameter Nuclepore polycarbonate filters were exposed to ambient air from the FAAM BAe-146 aircraft to collect in situ samples of accumulation- and coarse-mode aerosol particles (sizes $\sim 0.1$ to $\sim 10 \mu \mathrm{m}$ ). Such particle sizes are approximately applicable to the study of $\mathrm{CCN}$ and INPs (Pruppacher and Klett, 1997). Analysis of one below-cloud 


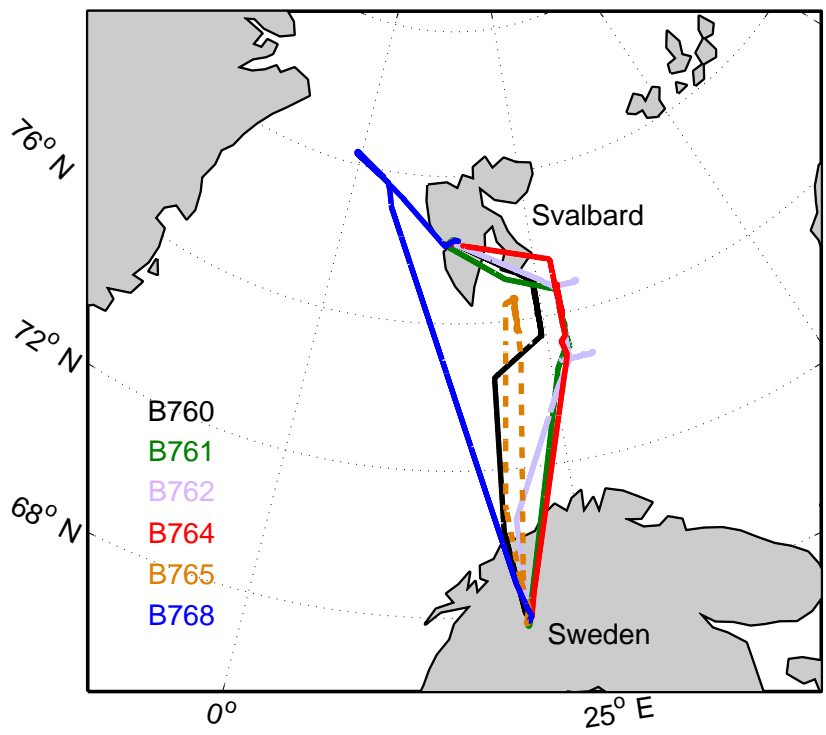

Figure 1. ACCACIA flight tracks of the main science periods undertaken for each flight where aerosol composition analysis was conducted.

set of filters from each case is shown, followed by a comparison between a below- and above-cloud pair from a single case study.

\section{Methodology}

\subsection{Aircraft instrumentation and trajectory analysis}

A range of cloud microphysics and aerosol instrumentation were used on board the FAAM BAe-146 aircraft to produce a detailed record of the observed Arctic atmosphere (as described by Liu et al., 2015; Lloyd et al., 2015). In this study, data from the Cloud Droplet Probe (CDP-100 Version 2, Droplet Measurement Technologies (DMT), Lance et al., 2010), the Cloud-Aerosol Spectrometer with Depolarisation (CAS-DPOL, DMT, Glen and Brooks, 2013) and the Passive Cavity Aerosol Spectrometer Probe (PCASP 100-X, DMT, Rosenberg et al., 2012) are used to provide context for and a comparison to the filter measurements. Throughout this article, the prefix $s$ is imposed to represent number concentration measurements computed at standard temperature and pressure.

The accumulation-mode aerosol distribution was monitored by the PCASP. The CAS-DPOL measured both coarsemode aerosol and, along with the CDP, cloud droplet number concentration. These externally mounted aircraft probes size and count their relative species via forward-scattering of the incident laser light through angles 35-120 and $\sim 4-12^{\circ}$ (for both the CDP and CAS-DPOL), respectively. The PCASP measures particle concentrations and sizes in the range of 0.1 to $3 \mu \mathrm{m}$, the CAS-DPOL provides similar measurements
Table 1. Details of FAAM flights undertaken during the spring segment of the ACCACIA campaign which had viable filter exposures. Corresponding filter case studies per flight are listed for reference.

\begin{tabular}{llll}
\hline Flight number & Date (2013) & Flight region* & Case studies \\
\hline B760 & 21 Mar & South-east & 1 \\
B761 & 22 Mar & South-east & 2 \\
B762 & 23 Mar & South-east & 3 \\
B764 & 29 Mar & South-east & 4,7 \\
B765 & 30 Mar & South & 5 \\
B768 & $3 \mathrm{Apr}$ & North-west & 6 \\
\hline
\end{tabular}

* With respect to Svalbard.

from 0.6 to $50 \mu \mathrm{m}$ (Glen and Brooks, 2013), and the CDP measures cloud droplets from 3 to $50 \mu \mathrm{m}$ (Rosenberg et al., 2012).

Out of cloud, the CDP was used to provide an indication of the wet-mode diameter of coarse-mode ambient aerosol particles. The CAS-DPOL also measures coarsemode aerosol concentrations when out of cloud. Within cloud, the liquid-water content (LWC) was derived from the observations of cloud droplet size. In this study, a LWC threshold of $\leq 0.01 \mathrm{~g} \mathrm{~m}^{-3}$, derived from CDP measurements, was employed to distinguish between out-of-cloud and incloud measurements. This threshold was applied to the CASDPOL, CDP and PCASP data to obtain an estimate of the ambient aerosol size distributions. These out-of-cloud observations are used in this study to validate the collection efficiency of the filter inlet system.

In addition to the in situ data gained from the instrumentation aboard the aircraft, back trajectory analyses were carried out to further contextualise the filter exposures. This was achieved using the National Oceanic and Atmospheric Administration HYbrid Single-Particle Lagrangian Integrated Trajectory (NOAA HYSPLIT 4.0) model (Draxler and Hess, 1998), in a similar manner to Liu et al. (2015). Horizontal and vertical wind fields were derived from GDAS reanalysis meteorology (Global Data Assimilation System; NOAA Air Resources Laboratory, Boulder, CO, USA) and used to calculate trajectories at $30 \mathrm{~s}$ intervals along the FAAM BAe-146 flight path. This analysis allows for the direction of the air mass to be inferred; however, it does not explicitly account for turbulent motions along the derived path and therefore carries a degree of uncertainty (Fleming et al., 2012). Trajectories dating back 6 days are presented to provide an indication of the source regions of the particles collected during the ACCACIA filter exposures.

\subsection{Filter collection}

The filter collection mechanism on the FAAM BAe-146 aircraft comprises a stacked-filter unit (SFU), which allows for two filters (Whatman Nuclepore track etch membranes) to be exposed simultaneously to the air stream, allowing aerosol 
particles to be collected on both. In the ACCACIA campaign, a combination of two filters with different nominal pore sizes was used in each exposure - a $10 \mu \mathrm{m}$ pore filter was stacked in front of a $1 \mu \mathrm{m}$ pore filter - allowing sub-micron aerosol particles that may pass through the pores of the first to be collected by the second.

The design of the inlet follows the same specifications as the UK Met Office C-130 aircraft filtration system described extensively by Andreae et al. (2000). Sub-isokinetic sampling conditions were maintained, potentially leading to a coarse-mode enhancement artefact (Chou et al., 2008). The design of the mechanism removes large cloud droplets from the sampled air using a bypass tube; therefore, contamination from droplets or rain is minimised (Chou et al., 2008; Johnson et al., 2012). Consequently, large particles $(>10 \mu \mathrm{m})$ are also thought to be removed from the collected sample, though the collection efficiency of the entire system is not known to have been formally quantified (Formenti et al., 2008; Johnson et al., 2012). Andreae et al. (2000) estimated the sampling efficiency of the inlet to be $35 \%$ by mass for the coarse mode, with a $50 \%$ cut-off threshold of $\sim 3 \mu \mathrm{m}$ (Formenti et al., 2003) and no losses identified for the accumulation mode. Chou et al. (2008) demonstrated that data collected via this inlet deviated from externally mounted particle counters above $\sim 0.5 \mu \mathrm{m}$, after which the coarse-mode enhancement on the filter samples became evident. Additionally, the efficiencies of the filters themselves can be estimated: the $50 \%$ cut-off diameter of the $10 \mu \mathrm{m}$ Nuclepore filter is approximately $0.8-1 \mu \mathrm{m}$ at the mean face velocity encountered during this study $\left(\sim 100 \mathrm{~cm} \mathrm{~s}^{-1}\right)$ (John et al., 1983; Crosier et al., 2007), whilst the $1 \mu \mathrm{m}$ filter has a $50 \%$ collection efficiency at approximately $0.2 \mu \mathrm{m}$ (Liu and Lee, 1976).

The filters were exposed on straight, level runs for approximately $10-30 \mathrm{~min}$ to obtain a sufficient sample for chemically speciated mass loadings. Although the filter system was designed to remove cloud droplets, the filters were primarily exposed out of cloud to further minimise the potential for contamination. Chosen filters were all exposed within the boundary layer $(<1000 \mathrm{~m}$, see Table 2$)$. Samples from below cloud were preferentially studied in this investigation (cases 1-6) as they likely included the main contributions of $\mathrm{CCN}$ and INPs at this time of year; however, one exposure from above cloud (case 7) is considered in Sect. 3.4.

\subsection{Scanning electron microscopy}

Using a Phillips FEI XL30 Environmental Scanning Electron Microscope with Field-Emission Gun (ESEM-FEG) in partnership with an energy-dispersive X-ray spectroscopy (EDS) system, automated single-particle analysis of the ACCACIA filter samples was undertaken at the University of Manchester's Williamson Research Centre (Hand et al., 2010; Johnson et al., 2012).
The coupled EDS system moves the sample stage through a pre-set grid to produce automated particle analysis of each sample. Particles are detected via the intensity of the backscattered electron signal. Grey-scale thresholds were set to identify particles under contrast with the background filter. The electron beam was then rastered over $70 \%$ of the detected particle surface to produce an X-ray spectrum: relative elemental weight percentages of elements from $C$ to $\mathrm{Zn}$ were recorded from the spectrum, measured and fitted with the $\mathrm{EDAX}^{\mathrm{TM}}$ Genesis software. For each measurement, standardless ZAF corrections were applied; corrections relating to atomic number, absorption and fluorescence. Parameters chosen for this analysis are listed in Table 3. A carboncoating was applied to each sample to allow high vacuum mode to be used. The minimum particle sizes detectable by each scan correspond to 4 pixels in the given image and are listed in Table 3 . The total number of particles scanned by the seven cases presented in this study is also listed in Table 3.

To act as a calibration, a blank filter pair was also analysed as Nuclepore filters have been shown to carry contaminants (Behrenfeldt et al., 2008). These were taken aboard the aircraft and treated similarly to the exposed filters. A small number of particles were identified: these appeared almost transparent under contrast and the majority produced a spectrum similar to the background filter. There was also a notable metallic influence and some particles were found to have moderate $\mathrm{Cr}$ or $\mathrm{Fe}$ fractions. These particles were found to be few in number and so should not greatly affect the outcome of this analysis.

Previous studies (e.g. Kandler et al., 2007; Hand et al., 2010; Formenti et al., 2011; Weinbruch et al., 2012) have shown that there are limitations to consider with this technique. The polycarbonate filters used during ACCACIA contaminate measurements of $\mathrm{C}$ and $\mathrm{O}$ in each particle detected. Studies using these filters have excluded $\mathrm{C}$ and $\mathrm{O}$ from their analysis to combat this issue (e.g. Krejci et al., 2005; Behrenfeldt et al., 2008; Hand et al., 2010). In this study, approximate thresholds of $\mathrm{C}$ and $\mathrm{O}$ are used to identify carbonaceous and biogenic species. However, only elements with $\mathrm{Z}>11$ (sodium) are used precisely within the classification scheme for the compositional analysis presented.

The electron beam produced by the scanning electron microscope (SEM) can negatively interact with some particle species, causing them to deform (Behrenfeldt et al., 2008). This is caused by the evaporation of the volatile components of the particles, either under the electron beam or as a result of the high vacuum (Li et al., 2003; Krejci et al., 2005). Little can be done to prevent this and it is difficult to manage when applying automated particle analysis. Behrenfeldt et al. (2008) found that this phenomenon only had a small impact on their results and could be disregarded. As a result, it can be assumed that the particles analysed by this method are dry and that any volatile components will have evaporated (Li et al., 2003). 
Table 2. Summary of sampling conditions during each filter exposure. The geographic positions are also listed. Values quoted are arithmetic means, with $1 \sigma$ in brackets where appropriate. In situ temperature data were collected with a Rosemount de-iced temperature sensor and the relative humidity $(\mathrm{RH})$ data were derived from Buck CR2 hygrometer measurements.

\begin{tabular}{llrrrrrrr}
\hline Case & $\begin{array}{l}\text { Conditions } \\
\text { sampled }\end{array}$ & $\begin{array}{r}\text { Exposure } \\
\text { length }(\mathrm{s})\end{array}$ & $\begin{array}{r}\text { Volume of } \\
\text { air }\left(\mathrm{s} \mathrm{dm}^{-3}\right)\end{array}$ & $\begin{array}{r}\text { Latitude } \\
\left({ }^{\circ} \mathrm{N}\right)\end{array}$ & $\begin{array}{r}\text { Longitude } \\
\left({ }^{\circ} \mathrm{E}\right)\end{array}$ & $\begin{array}{r}\text { Altitude } \\
(\mathrm{m})\end{array}$ & $\begin{array}{r}\text { Temperature } \\
\left({ }^{\circ} \mathrm{C}\right)\end{array}$ & $\begin{array}{r}\text { RH } \\
(\%)\end{array}$ \\
\hline 1 & Clear & 600 & $2312.3^{\mathrm{b}}$ & 76.2 & 24.5 & $102(5)$ & -11 & 91.9 \\
2 & Clear $^{\mathrm{a}}$ & 1700 & 2608.4 & 76.4 & 26.5 & $238(107)$ & -8 & 96.8 \\
3 & Cloud haze & 660 & 826.4 & 76.8 & 28.0 & $375(5)$ & -18 & $108.4^{\mathrm{c}}$ \\
4 & Clear & 540 & 754.8 & 76.6 & 27.2 & $91(86)$ & -9 & 97.4 \\
5 & Clear & 961 & 1249.3 & 76.2 & 22.0 & $71(18)$ & -9 & 96.5 \\
6 & Clear & 240 & 272.7 & 79.9 & 2.8 & $98(44)$ & -8 & 95.3 \\
7 & Clear & 720 & 1080.2 & 76.4 & 27.1 & $833(59)$ & -13 & 86.9 \\
\hline
\end{tabular}

a Filter was collected mostly under clear conditions, although some in-cloud sampling was encountered at the end of the exposure. ${ }^{b}$ The total volume of air sampled during case 1 is high given its exposure length due to higher-than-average flow rates applied during that flight.

c Contaminated measurement, likely due to condensation on detection surface.

Table 3. Main parameters applied with SEM and $\operatorname{EDAX}^{\mathrm{TM}}$ Genesis software to carry out analysis of the ACCACIA aircraft filters.

\begin{tabular}{|c|c|c|}
\hline \multicolumn{3}{|c|}{$\mathrm{SEM} / \mathrm{EDAX}^{\mathrm{TM}}$ Genesis analysis parameters } \\
\hline Beam voltage $(\mathrm{kV})$ & & 5 \\
\hline Working distance $(\mathrm{mm})$ & & 0 \\
\hline Operating current $(\mu \mathrm{A})$ & & 200 \\
\hline Beam spot size & & 4 \\
\hline Image resolution (px) & 1024 & $\times 800$ \\
\hline Total number of particles & 139 & 630 \\
\hline Magnifications applied & $4000 \times$ & $1000 \times$ \\
\hline Filters analysed & 1 and $10 \mu \mathrm{m}$ & $10 \mu \mathrm{m}$ \\
\hline Min. particle size $(\mu \mathrm{m})$ & 0.13 & 0.52 \\
\hline Field sizes $(\mathrm{mm})$ & $0.059 \times 0.046$ & $0.237 \times 0.185$ \\
\hline
\end{tabular}

There are also several implicit factors, which may contribute some degree of uncertainty to the quantitative composition measurements gained. For example, errors can be introduced by uncertainties in the spectral fitting of the $\operatorname{EDAX}^{\mathrm{TM}}$ software (Krejci et al., 2005) or from the differing geometries of the individual particles measured (Kandler et al., 2007). Also, compositional data for particles less than $0.5 \mu \mathrm{m}$ suffer from increased uncertainty (Kandler et al., 2011). The sample sizes considered here were too large to consider individual corrections; therefore, the measurements from the EDS analysis were taken as approximate values. Similarly, manual inspection of the images and spectra was not feasible due to the sample size and so an algorithm was imposed to remove any filter artefacts. These were typically a result of the software misclassifying the filter background as a particle itself and therefore displayed only the distinctive background signature. This background spectrum presented different characteristics than those considered to be carbon based; the artefacts were noisy, with very low detections in all but a few of the elements, whereas the particles thought to be carbonaceous displayed zero counts in some elements as expected. The fraction of detected particles removed by this algorithm was typically low $(\sim 4-5 \%)$, yet it is not possible to conclude if any real particles were removed. Krejci et al. (2005) placed an estimate of the total error involved with this technique to be around $10 \%$ and found this value to be dependent on the sample and elements analysed.

\subsection{Classifications}

Elemental information gained from EDS analysis was taken further to identify particle species relevant to the atmosphere. The classification scheme applied in this investigation was derived from a variety of sources (e.g. Krejci et al., 2005; Geng et al., 2010; Hand et al., 2010); however, it is most prominently based upon the detailed scheme presented by Kandler et al. (2011). This scheme is detailed in Table S1.

\subsubsection{Carbonaceous and biogenic}

Approximate thresholds of $\mathrm{C}$ and $\mathrm{O}$ were utilised to distinguish carbonaceous and biological particles (Mamane and Noll, 1985). This approach has been adopted by other studies that applied a polycarbonate substrate (e.g. Kandler et al., 2007; Behrenfeldt et al., 2008; Hand et al., 2010). For example, particles included in this category could be soot particles or pollen grains (Behrenfeldt et al., 2008). Soot has been previously identified by introducing other properties into the classification process; for example, Hara et al. (2003) and Hand et al. (2010) categorised it via its characteristic chain-aggregate morphology. Due to the sample size, inspection of particle morphologies was not feasible in this study; therefore, carbonaceous particles were not specifically categorised.

Carbonaceous and biogenic particles have been segregated using compositional information in previous studies. Mamane and Noll (1985) measured distinctive small peaks in $\mathrm{P}, \mathrm{S}, \mathrm{K}$ and/or $\mathrm{Ca}$ with a dominating $\mathrm{C}$ influence in pollen grains. Similarly, Geng et al. (2010) utilised a comparable 
threshold, also considering small amounts of $\mathrm{Cl}, \mathrm{S}, \mathrm{K}, \mathrm{N}$ and/or $\mathrm{P}$ as indicators for biogenic species as these elements are important nutrients for plant life (Steinnes et al., 2000).

The carbonaceous and biogenic classifications likely include particles that may have some volatile component, which cannot be measured by this technique (see Sect. 2.3). The partial or complete evaporation of these particles therefore renders the presented fraction a lower limit; i.e. only the non-volatile cases could be measured. Coupled with the difficulty of distinguishing these particles from the filter background, it is important to note that the fractions of carbonaceous and biogenic classes presented by this study are approximations which are likely underestimating the true organic loading on these filters.

\subsubsection{Sulfates, fresh and mixed chlorides}

Sodium chloride $(\mathrm{NaCl})$ from sea salt can enter the atmosphere as a consequence of sea-surface winds and these particles remain predominantly $\mathrm{Na}$ - and $\mathrm{Cl}$-based for a short period of time. The lifetime of $\mathrm{Cl}$ is hindered by the tendency of these particles to accumulate sulfate in the atmosphere, thus producing particles primarily composed of $\mathrm{Na}-\mathrm{S}$ (Hand et al., 2010). Due to this short lifetime, its presence is often used to indicate a fresh contribution from the sea surface (Hand et al., 2010). It is a common conclusion that a lack of Cl-containing particles and/or a significant fraction of $\mathrm{S}$ in a particulate sample is suggestive of aged aerosol (Behrenfeldt et al., 2008; Hand et al., 2010).

Aerosol containing S can infer an anthropogenic influence in a sample, as they are thought to have undergone a reaction with sulfur oxides (Geng et al., 2010). However, the Arctic Ocean is a natural source of dimethylsulfide (DMS), a gas which can also interact in the atmosphere to form sulfur dioxide. The contribution of this source is greater during the summer months due to decreased sea ice (Quinn et al., 2007), and is thought to have little influence during the dates of this study. The gas source cannot be concluded here but it can be stated that $\mathrm{Na}-\mathrm{S}$ particles will have been present in the atmosphere for a sufficient length of time to allow for the interaction to take place.

The mixed chlorides category requires that particles must still be predominantly $\mathrm{Na}$ - and $\mathrm{Cl}$ - based, with a notable $\mathrm{S}$ contribution. This category also accounts for metallic contributions to the base $\mathrm{NaCl}$ species. The sulfates and fresh chloride categories are limited to the extremes of this distribution, with only S- and Cl-dominated signatures allowed respectively.

\subsubsection{Silicates, mixed silicates, Ca-rich and gypsum}

Complex internal mixing in particles is often indicative of a natural origin (e.g. Conny and Norris, 2011; Hoose and Möhler, 2012); however, coagulated particles can also be produced by high-temperature anthropogenic activities. A strong method of sourcing internally mixed particles involves the identification of $\mathrm{Si}$ : particles consisting of this element and various mixed metals are likely to be naturally occurring mineral dusts, and industrial by-products may lack this element in high quantities (Conny and Norris, 2011). Mineral dusts are typically composed of a variety of elements and tend to include significant fractions of $\mathrm{Si}$ and $\mathrm{Al}$, with more minor contributions from $\mathrm{Na}, \mathrm{Mg}, \mathrm{K}, \mathrm{Ca}$ and/or $\mathrm{Fe}$ amongst others.

Dusts are crucial constituents of the aerosol population as they are proven INPs (Zimmermann et al., 2008; Murray et al., 2012; Yakobi-Hancock et al., 2013). However, they can also act as CCN; for example, Ca-based dusts have been shown to form hygroscopic particles after reaction with nitrates in the atmosphere (Krueger et al., 2003). The springtime concentrations of nitrates in the Arctic (measured at the Alert sampling station in Canada) followed an increasing trend over 1990-2003 (Quinn et al., 2007), suggesting it is probable that this interaction could take place in this environment. Alternatively, internally mixed particles consisting of dusts, sulfates and sea salt can act as giant CCN (Andreae and Rosenfeld, 2008). In this study, the presence of such particles may be inferred by the detection of $\mathrm{S}$ or $\mathrm{Cl}$ with the typical dust-like signatures. This can occur if the dust in question has been transported over long distances and thus undergone cloud processing or acidification reactions (Mamane and Noll, 1985; Behrenfeldt et al., 2008). Or, more simply, these could be the result of a sea salt or sulfate coating on a mineral dust particle, and such mixtures have been modelled to have significant effects on warm clouds by augmenting the CCN population (Levin et al., 2005). Complex internal mixtures containing $\mathrm{Si}, \mathrm{S}$ and/or $\mathrm{Cl}$ are therefore indicated in this study under the classification mixed silicates.

The mineral phase of aluminosilicates cannot be identified using the EDS method as these particles are closely related compositionally. The specific phases of dusts observed in SEM studies are often not quantified for this reason (Kandler et al., 2007; Hand et al., 2010). Instead, the individual X-ray counts and ratios between the elements measured were considered to classify their sampled particles into approximate groups such as silicates and carbonates. It has often been considered that $\mathrm{Al}, \mathrm{Ca}$ and $\mathrm{K}$ are indicative of aluminosilicates (such as kaolinite), carbonate minerals such as calcite $\left(\mathrm{CaCO}_{3}\right)$ and dolomite $\left(\mathrm{CaMg}\left(\mathrm{CO}_{3}\right)_{2}\right)$ - and clays/feldspars respectively (Formenti et al., 2011). Due to the lack of a quantitative $\mathrm{C}$ measurement, carbonate minerals were inferred from their $\mathrm{Ca}$ and $\mathrm{Mg}$ abundances in this study. Some mineral classes have a distinct elemental relationship and these can be classified; for example, gypsum $\left(\mathrm{CaSO}_{4} \cdot 2 \mathrm{H}_{2} \mathrm{O}\right)$ samples typically do not deviate from their base chemical formulae (Kandler et al., 2007). By this reasoning, gypsum was included as its own classification, whereas the vast majority of mineral dusts observed were grouped into the silicates, mixed silicates and Ca-rich categories, dependent on the relative quantities of $\mathrm{Si}, \mathrm{S}$ and $\mathrm{Ca}$ they contained. 


\subsubsection{Phosphates and metallics}

These groups include particles with significant influences from $\mathrm{P}$ and transition metals. Particles classified as phosphates in this study may include those composed of apatite - a Ca- and P-based mineral group - as factories which process these minerals are common in the nearby Kola Peninsula, Russia (Reimann et al., 2000).

The presence of transition metals can be viewed as an indicator for an industrial origin (Weinbruch et al., 2012). Potential local anthropogenic sources for the metallic particles include the coal burning facilities on Svalbard (in Longyearbyen and Barentsburg) or various metal smelters in the Kola Peninsula, Russia (Weinbruch et al., 2012). The metals included in the EDS analysis were $\mathrm{Ti}, \mathrm{Cr}, \mathrm{Fe}, \mathrm{Ni}, \mathrm{Cu}$ and $\mathrm{Zn}$. Contributions from these may be attributable to anthropogenic and/or natural sources and could be in the form of metal oxides or constituents of complex minerals (Hand et al., 2010). Of those measured in this study, $\mathrm{Fe}$ and $\mathrm{Al}$ are the most likely to originate from a variety of sources as they are processed widely (Steinnes et al., 2000) and are common constituents in silicate-based dusts. Similarly, Zn may also be associated with biological material in addition to smelting emissions (Steinnes et al., 2000).

\subsubsection{Biomass tracers}

This group was introduced out of necessity given the results obtained. The other classifications were expected from hypothesised local sources; however, this group was introduced to account for the high quantity of K-based particles observed in one of the flights. These particles have negligible measurements of Si and are not thought to be mineralogical in nature. This category has been dubbed "biomass tracers" as several studies (e.g. Andreae, 1983; Chou et al., 2008; Hand et al., 2010; Quennehen et al., 2012) have identified particles sourced from biomass burning events to be rich in this element. These K-rich particles have been found to be prominent in forest fire and anthropogenic combustion emissions. It is unlikely that such particles could be sourced in the Arctic; therefore, their presence may infer transport from elsewhere (Quennehen et al., 2012). Biomass burning produces particles known as bottom ashes, which differ from the fly ash particles that are typically emitted during fossil fuel incomplete combustion processes (Umo et al., 2015). Activities which may produce these constituents could include firewood or agricultural burning (Andreae, 1983), or wildfires in warmer climates (Seiler and Crutzen, 1980).

\subsubsection{Other}

Particles which are not classified by the applied scheme are classed as other. The implication is that these particles are mixed. Figure 2 illustrates the difficulty with mixed particles; though local sites on the particle may be dominated by cer-

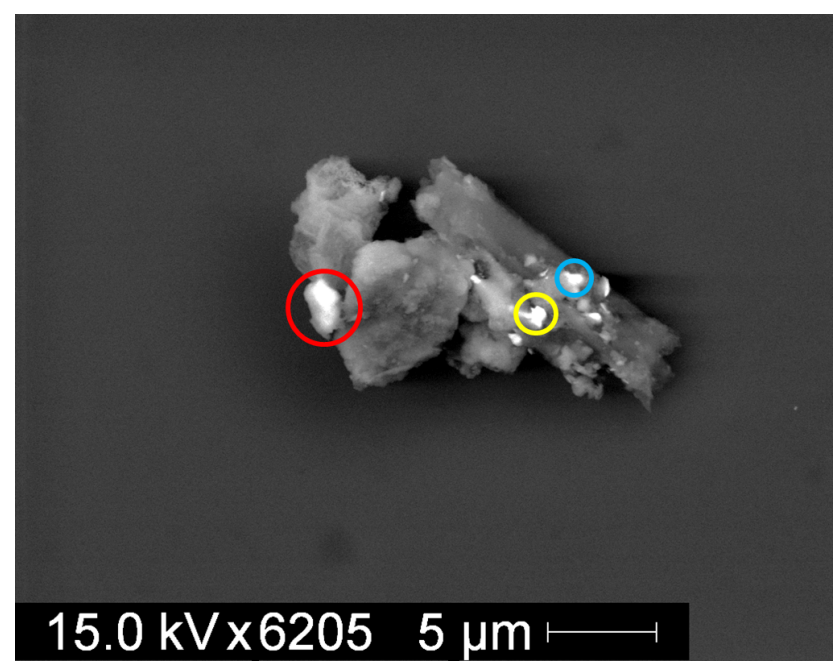

Figure 2. Mixed particle from case 5. The circles denote the spots scanned to give the following dominating elements: Red - Fe, Si and $\mathrm{Al}$; Yellow - Fe, Cr, Ni, Si and Al; Blue - Fe, Cr, Ca, Cl, S, Si and Al. Scan of full particle indicates Si dominance.

tain elements, the SEM analysis does not provide a spatial map of the elemental distribution across each particle surface.

Mixed particles are typically either unclassified or classified by their most abundant elements. The particle illustrated in Fig. 2 would be classified as a silicate dust as it is mixed but has a dominating Si influence. The size of the samples prevent manual inspection of every unclassified particle; therefore, the abundance of mixed particles within a data set must be inferred from the quantity quoted as "Other".

\section{Results}

\subsection{HYSPLIT back trajectories}

Air mass histories were calculated using HYSPLIT for each of the filter exposures to provide context with the environmental conditions in which they were sampled. Figure 3 shows the spatial extent of these trajectories in the top two panels and the mean altitudes covered are displayed in the bottom panel.

The mean altitude of the trajectories remains within the lower $1.5 \mathrm{~km}$ of the atmosphere. The modelled altitude typically increases with increased time backwards. Case 5 is the exception to this trend, as consistent low-altitude trajectories are modelled for the full duration shown. Also, the majority of these trajectories are reasonably smooth; however, a significant descent in height is modelled in case 4 at approximately -2 days.

A north-easterly wind was observed for cases 1 to 3 , bringing air from over the dense Arctic sea ice to the region of interest to the south-east of Svalbard. When extended back 

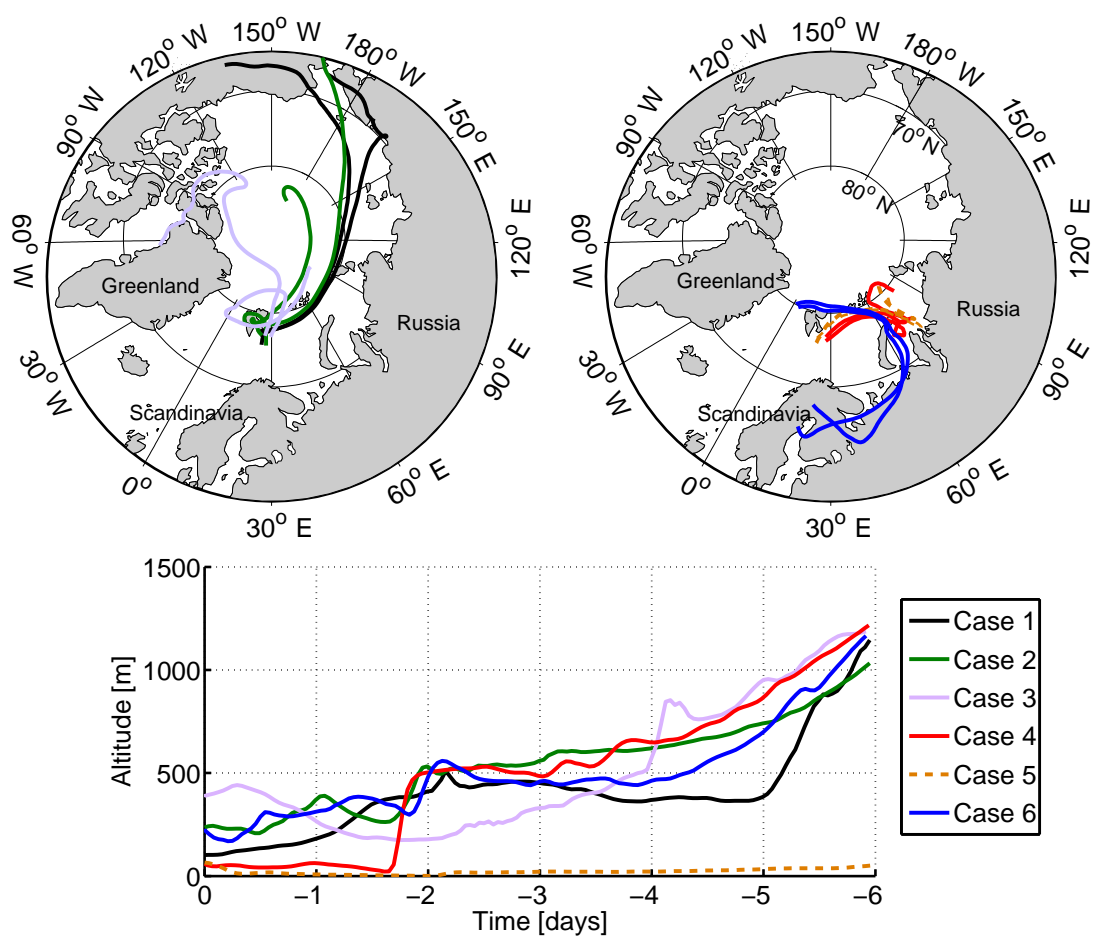

Figure 3. HYSPLIT air mass back trajectories for cases 1-6, initialised at the aircraft's position and calculated 6 days backwards. Trajectories at the beginning and end of each exposure are shown. Top left panel: cases 1 (black), 2 (green) and 3 (purple); top right panel: cases 4 (red), 5 (orange) and 6 (blue). The mean altitude covered by each of these trajectory groups is shown in the bottom panel.

by 6 days, differences between the air mass histories can be seen. From Fig. 3, cases 1 and 2 show some similarities, with the latter displaying more curvature anticlockwise than the former. Trajectories from case 3 are distinct from these two, with cyclonic curvature around the immediate vicinity of Svalbard and Greenland.

There is a clear partition in the direction of the trajectories as the spring campaign progressed. The first three exposures had source regions to the north and west of the exposure locations, whilst the latter three primarily sampled from the east. These latter trajectories are also more compact than the first three cases (Fig. 3). The air from cases 4 and 5 is traced back across the northern coast of Russia, whilst case 6 covers both the northern coast of Russia and Scandinavia. A large portion of these trajectories are clustered towards the continent, suggesting a strong influence from this region.

These two trajectory groups can be dissected further; two specific pairs can be identified (cases 1 and 2; 4 and 5), which display similar paths, and cases 3 and 6 appear unique in comparison. Overall, there appears to be a clear shift in the source region of these boundary layer exposures as the campaign progresses; from over the dense Arctic sea ice, through Greenland and northern Russia to the European continent.

\subsection{Aerosol size}

To investigate any issues with inlet collection efficiency (see Sect. 2.2), size distributions from the filter data were constructed and compared with arithmetic means of the wingmounted probe data over each exposure period. Number size distributions were computed similarly to Chou et al. (2008); namely, the total number of particles detected in each scan was normalised by the area covered and total volume of air sampled, then scaled to the full filter area. Figure 4 illustrates these comparisons for each below-cloud filter pair analysed. Data from the PCASP, CAS-DPOL and CDP instruments are shown for comparison. These data use the standard scattering cross sections for the aircraft probes and no refractive index corrections were applied due to the expected mixed aerosol population.

Agreement between the filter-derived and the probe data appears dependent on the conditions sampled. For example, case 3 was exposed during a section where cloud haze was encountered, whereas cases 1, 5 and 6 were cleanly exposed out of cloud. Cases 2 and 4 sampled small amounts of cloud at the end of their exposures - at which point the probes measured some amount of cloud droplets and/or swollen aerosol particles - therefore, the probe distributions differ somewhat from the filter-derived particle distributions. Mean relative humidity $(\mathrm{RH})$ values (Table 2) from each exposure were high $(>90 \%)$ and the disagreement between filter and probe 

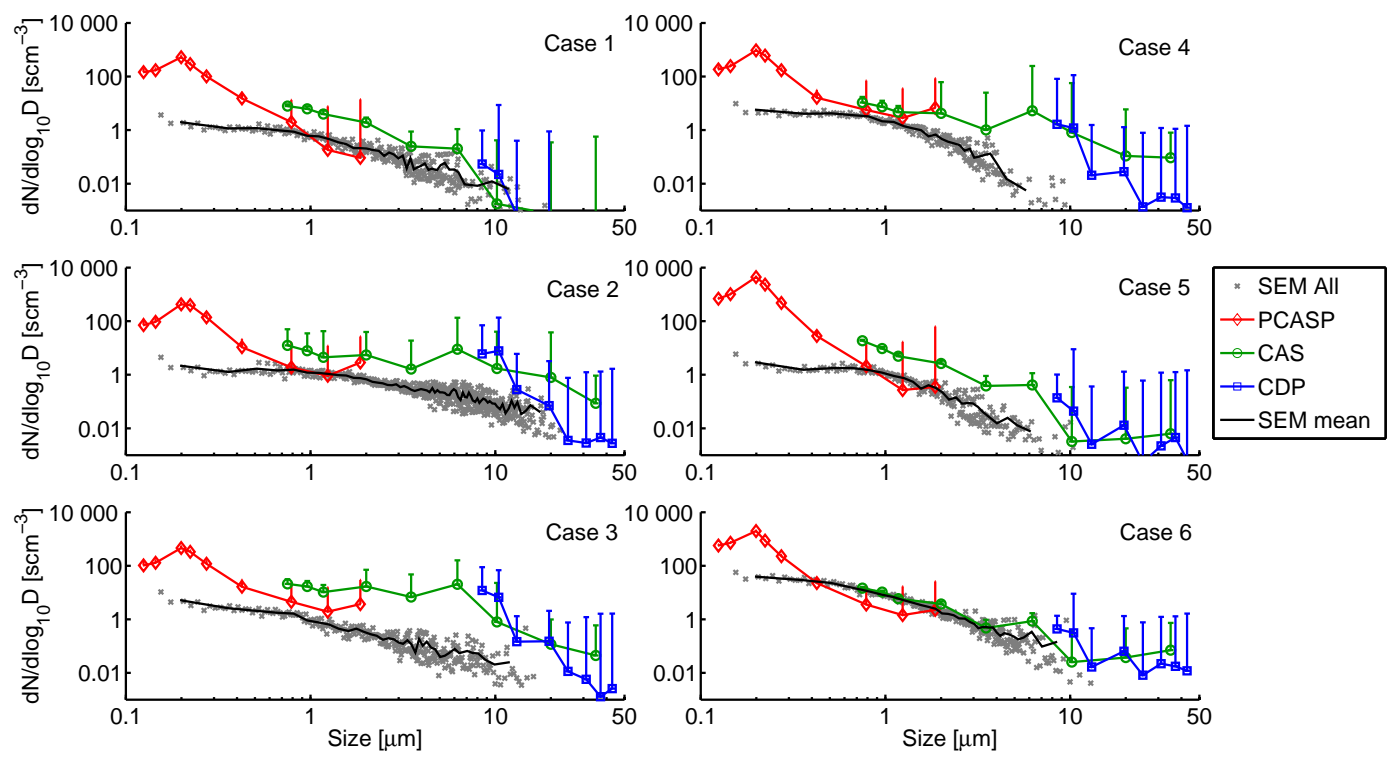

Figure 4. Size distributions $\left(\mathrm{dN} / \mathrm{dlog}_{10} \mathrm{D}\right)$ of particle data obtained via SEM analysis compared with averaged distributions from the optical particle counters at the relevant filter exposure times. Number concentrations are quoted with standard temperature and pressure corrections $\left(\mathrm{s} \mathrm{cm}^{-3}\right)$. PCASP, CAS and CDP data are shown in red (diamonds), green (circles) and blue (squares) respectively. Only upwards error bars are shown for clarity. SEM data are shown as scatter points (grey, crosses) and the arithmetic mean of these data is shown in black.

data in Fig. 4 appears to correlate with these values. Case 1 displays good agreement under lower RH conditions, whilst cases 2, 3, 4 and 5 display poorer agreement under higher $\mathrm{RH}$ conditions. However, case 6 displays good agreement under relatively high $\mathrm{RH}$. The derived $\mathrm{RH}$ values are similar; therefore, these trends could be circumstantial. The RH measure for case 3 is not trusted and is likely a consequence of condensation on the detection surface.

Qualitatively, there is reasonable agreement between the probe and SEM-derived number size distributions - providing confidence in the analysis presented - but this similarly highlights the limitations of the sample inlets on the aircraft for coarse aerosol as described by Trembath (2013). The discrepancies between these distributions, with relation to the inlet efficiency issues, are addressed further in Sect. 4.1.

\subsection{Aerosol composition}

The particle classifications detailed in Table S1 in the Supplement were applied to the compositional data obtained for each analysed filter pair. The dependence of composition on size is shown in Fig. 5, where only sizes which display good agreement with the wing-mounted probes have been included $(\sim 0.5-\sim 10 \mu \mathrm{m})$. Data out with this range was viewed as being unrepresentative of the population, given the discrepancies at small and large sizes in Fig. 4.

Clear trends become apparent when implementing this size-segregated approach. Silicate dusts are identified in all samples, with greater concentrations found at larger sizes in all cases except the last. These dusts are especially abundant in the first three cases. Cases 4 and 5 are dominated by fresh chlorides at all sizes except the largest bins, and cases 3 and 6 also contained significant fractions of this species. Case 6 differs from the others, displaying increased Ca-rich, mixed chloride and other fractions. Similarly, the high sulfate loading in case 1 is unique, yet the composition trends of this case can be associated with the subsequent flight via the abundance of silicates; a link that is not so clear between cases 5 and 6.

Although the mineral phase cannot be identified, elemental ratios can be used to identify trends in the dust samples. For example, feldspars can be rich in $\mathrm{Ca}, \mathrm{K}$ or $\mathrm{Na}$, whilst clays may have significant fractions of $\mathrm{Mg}$ and/or Fe. The elemental ratios displayed in Fig. 6 are variable across the campaign. This variability is heightened in some ratios with respect to others; from Fig. 6, the $\mathrm{K} / \mathrm{Al}$ and $\mathrm{Ca} / \mathrm{Al}$ ratios are changeable but the $\mathrm{Mg} / \mathrm{Si}$ ratio is low for all cases. The mean and median values of the $\mathrm{Si} / \mathrm{Al}$ ratio do not differ substantially between the flights, whilst the $\mathrm{K} / \mathrm{Al}, \mathrm{Fe} / \mathrm{Si}$ and $\mathrm{Ca} / \mathrm{Al}$ ratios are heightened in case 6 .

\subsection{Comparison between below- and above-cloud samples}

The samples detailed previously were all exposed below cloud and were chosen as the particles collected likely influenced the microphysics of clouds that formed above these collection altitudes. Most of these cases appear to be influenced by local sources; cases 4 and 5 in particular are predominantly composed of fresh chlorides. However, these 

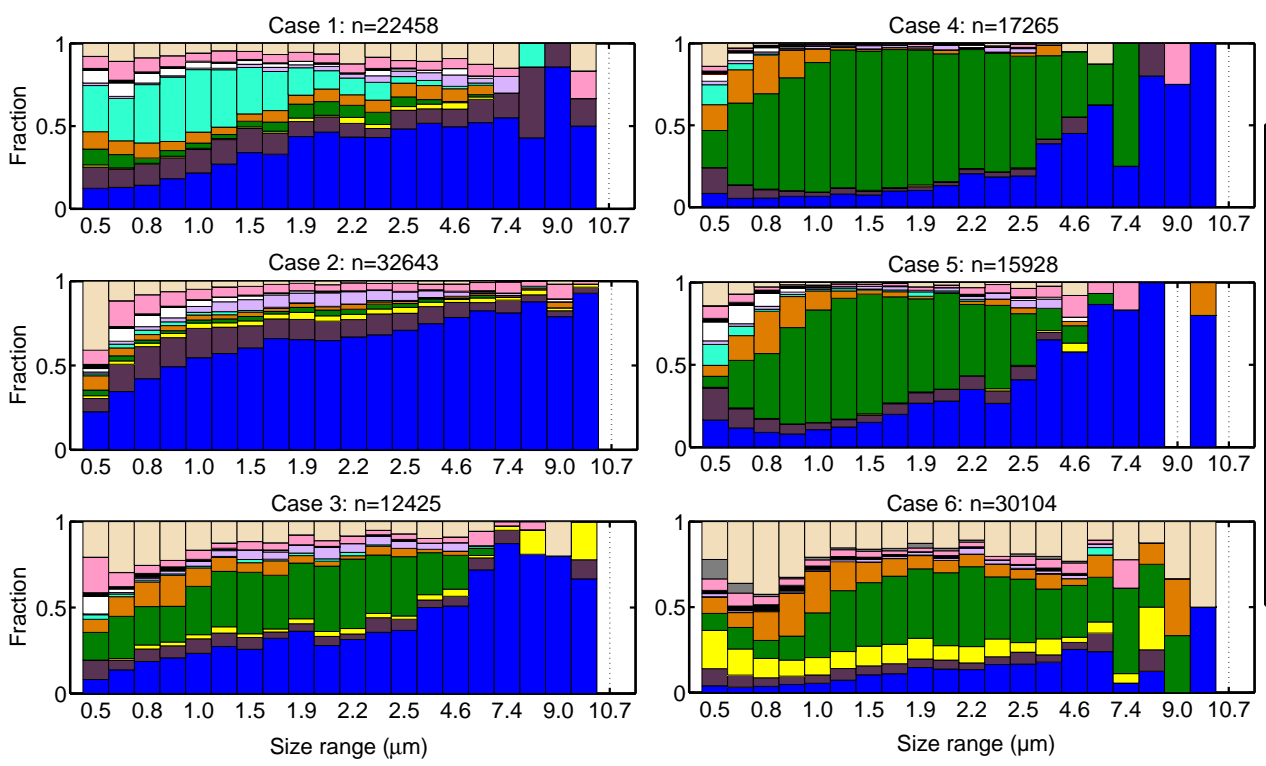

Figure 5. Size-segregated particle classifications applied to each below-cloud case, with each size bin normalised to show the fraction (by number) occupied by each classification. The sizes indicated are the bin centres. The number of particles scanned in each case is listed at the top of each panel.

cases do not obviously address the involvement of aerosol particles from distant sources.

As a test case, a filter pair exposed above cloud was analysed to compare the particle compositions. A comparison study was chosen: flight B764 provided consecutive filter exposures below and above (cases 4 and 7) a stratus cloud deck, approximately $1 \mathrm{~h}$ apart, allowing for a comparison between the respective compositional characteristics. The cloud located between the exposures was mixed-phase, with a measured sub-adiabatic CDP liquid-water content profile. This suggests that entrainment of aerosol from above may have been an important source contributing to changes in the cloud microphysical properties (Jackson et al., 2012), or that the liquid-water in the cloud had been depleted via precipitation processes. Air mass back trajectories varied little between the exposures, with both cases influenced by air from over the Barents Sea and the coast of northern Russia (see Fig. 3). The conditions sampled during each of these exposures are summarised in Table 2.

Figure 7 displays the compositional differences between the below- and above-cloud samples. The fraction of unclassified particles is greater in the above-cloud example for sizes $>0.5 \mu \mathrm{m}$ (panel b), whilst a similar fraction was observed in both cases for sizes $\leq 0.5 \mu \mathrm{m}$ (panel a). Similarly, a comparable fraction of silicates is identified on both filter pairs. Greater fractions of fresh chlorides are found in case 4; however, a moderate loading of sea salt - and aged sea salt - is still identified in case 7. Case 7 also has a greater sulfate loading and the absolute number of particles detected was lower than in the below-cloud case. The size-segregated classifications, shown in panel c of Fig. 7, display significant unclassi- fied fractions across most sizes, with increased contributions at $<1$ and $>3 \mu \mathrm{m}$. The dominating species changes from unclassified to fresh chlorides to silicates as particle size increases and significant mixed chloride fractions are also observed at small sizes.

\section{Discussion}

\subsection{Size distributions}

The filter-derived and probe-averaged size distributions from Sect. 3.2 compare reasonably well. The disagreement at the size limits $(\lesssim 0.5$ and $\gtrsim 10 \mu \mathrm{m})$ of these distributions implies that the inlet collection and filter efficiency issues discussed in Sect. 2.2 were influencing these samples. These collection issues have been found to have the greatest impact on the coarse mode (Andreae et al., 2000; Formenti et al., 2003). The results shown in Fig. 4 reflect this, where the agreement between the filter- and probe-distributions decreases with increasing size $(\gtrsim 1-2 \mu \mathrm{m})$. Coarse-mode enhancement relative to the probe data is not observed to the same extent as Chou et al. (2008). Reasonable agreement between these data is observed up to approximately $10 \mu \mathrm{m}$, as also concluded by Johnson et al. (2012) - whose samples were analysed using the same facilities in the Williamson Research Centre - and Chou et al. (2008).

Disagreement $<0.5 \mu \mathrm{m}$ could be due to particles either passing through the filter pores at the time of exposure or being left undetected by the EDS analysis due to a decreasing signal-to-noise ratio and increasing interaction volume in this size limit (Kandler et al., 2011). Chou et al. (2008) 


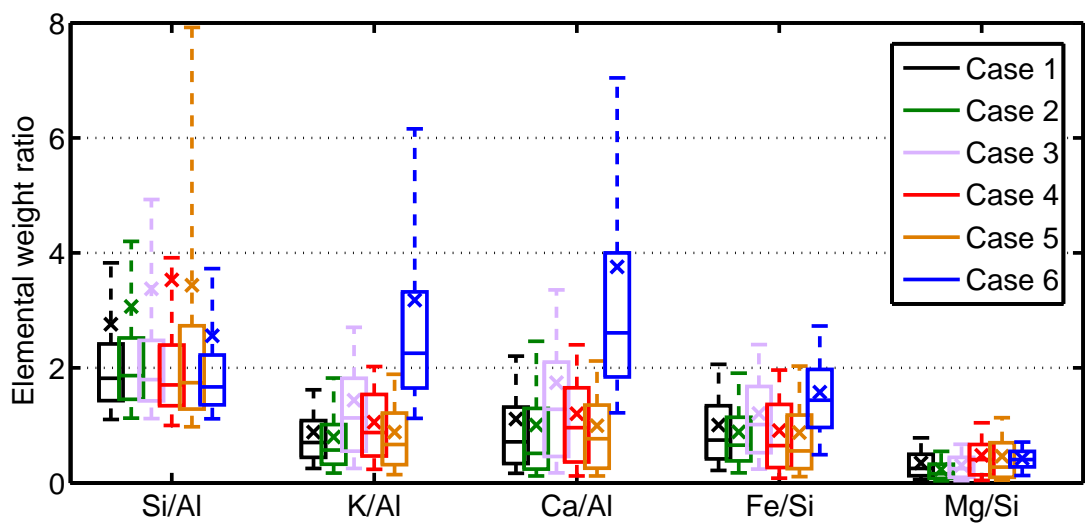

Figure 6. Mean elemental ratios from each case. Data from the silicates and mixed silicates categories only are included to provide an indication of the mineral phases measured. Box edges indicate the 25th and 75th percentiles, and the cross and the horizontal line dissecting the boxes represent the mean and median values respectively. The outliers extend to the 10 and $90 \%$ thresholds of the data.

found that their accumulation-mode filter size distributions derived from transmission electron microscopy (TEM) correlated better with observational data obtained from a cabinbased PCASP variation sampling from a Counterflow Virtual Impactor inlet (CVI-PCASP) than their SEM-derived distributions. Given the similarity between the filtration techniques applied, this may suggest that the disagreement between the accumulation-mode distributions observed here could be a result of the limitations of the SEM technique rather than an issue with the filter sampling on the aircraft. However, Chou et al. (2008) also identified differences between the performance of their CVI-PCASP and externally mounted PCASP - with the former consistently overcounting compared to the latter - suggesting that possible inlet losses could be similarly affecting the wing-mounted PCASP used in this study. In summary, the SEM technique, filter mechanism collection efficiency, and possible inlet losses could all be introducing some magnitude of error to the comparisons shown in Fig. 4, and it is not trivial to identify which source of error is the most influential in these cases.

\subsubsection{Cases 1 to 5}

The compositional trends observed in Fig. 5 are typically different between each case. Compositional dominance varies from sulfates to silicates to fresh chlorides through the first five cases. Some particle classes, e.g. carbonaceous or sulfates, are mostly observed at sizes $<1 \mu \mathrm{m}$ (excluding case 1 ), whilst others (e.g. silicates) are more common at larger particle sizes.

The influence of sulfates, silicates and fresh chlorides varies substantially in the first five cases; variability which could be inferred from the differences in the respective back trajectories. There are distinct similarities between the trends derived for cases 4 and 5, with dominant fresh chloride and silicate signatures observed (Fig. 5). Both cases display a similar mixed chloride loading between sizes 0.5 and $1 \mu \mathrm{m}$; particles which are likely sea salts mixed with sulfates.

The chloride classifications are not ubiquitously observed in the first five cases, with particularly low measurements of these species in cases 1 and 2. This suggests that the ocean was not a strong source of particles in these cases, whereas the significance of this source is clear in cases 3, 4 and 5 . This hypothesis is strengthened by the back trajectories calculated for these exposures (Fig. 3); the air mass source for cases 1 and 2 was the frozen Arctic Ocean, whilst cases 4 and 5 both had low-altitude trajectories across the sea surface. During the transition over the ocean, sea salts could have been lifted into the air stream. Case 1 displays a high sulfate signature - a characteristic unique from the other cases - suggesting that these particles had sufficient time to interact with sulfate gases (from either anthropogenic or marine sources, see Sect. 2.4.2) during transit over the sea ice. There is a common link between the first three cases in their respective silicate loadings; the measured amount of silicate-based dusts is high in these cases, with a maximum reached during case 2. Potential sources of these dusts are discussed further in Sect. 4.2.

\subsubsection{Case 6}

Case 6 was exposed in a different location - to the northwest of Svalbard instead of the south-east - than the first five cases (see Table 1). The particle loading was much greater for this case, as indicated by the large number of particles collected (Fig. 5) and the very short sampling time (Table 2). The comparatively greater number concentration measured agrees with the aerosol climatology presented by Tunved et al. (2013) and results from the Arctic Study of Tropospheric Aerosol and Radiation (ASTAR) 2000 campaign (Hara et al., 2003), where trajectories from northern Russia and Europe coincided with noted "haze" events with increased particle loadings. Additionally, there are distinct 


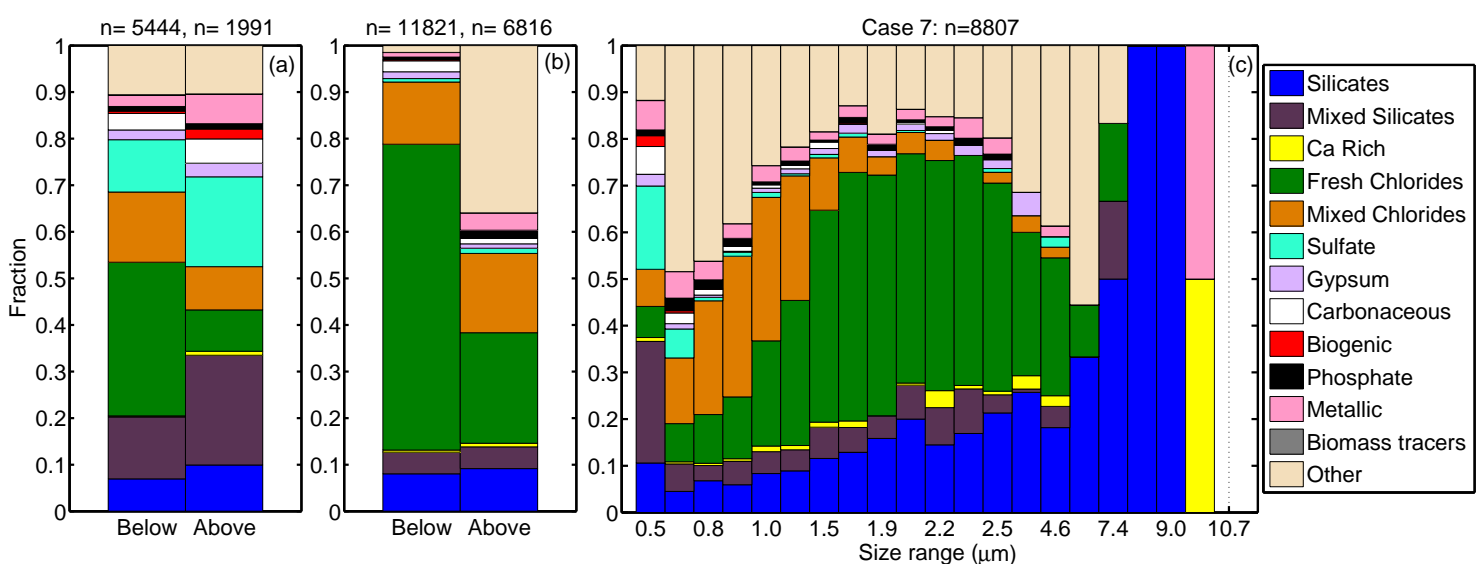

Figure 7. Compositional comparison between the below- and above-cloud samples (cases 4 and 7) from flight B764. (a) Averaged particle classifications $\leq 0.5 \mu \mathrm{m}$; (b) averaged particle classifications $>0.5 \mu \mathrm{m}$; (c) size-segregated classifications from the above-cloud exposure. Each bin is normalised to show the fraction (by number) occupied by each classification and the number of particles analysed are listed above each panel. The sizes indicated in (c) are the bin centres.

compositional differences between cases 1-5 and case 6 . This case is the only one not to be dominated by silicates at super-micron sizes and has the greatest proportion of Ca-rich particles, biomass tracers and unclassified particles across the sizes considered. Case 6 is unique in its dominant particle categories, their respective size evolution, and air mass back trajectory, emphasising its contrast to the other cases.

The magnitude of the biomass tracer fraction is only sufficient enough to be observed in case 6 . These particles are mostly small in size, as shown in Fig. 5. Andreae (1983) have previously shown that there is a strong relationship between biomass particle species and particle size below $2 \mu \mathrm{m}$. The $\mathrm{K}$ measurements in these particles mirror the quantities measured by Umo et al. (2015) for bottom ashes, adding confidence to their identification as biomass products. Modelled back trajectories for case 6 hail from northern Russia and the European continent. Potential sources of these particles could include similar boreal forest fire events as those sampled by Quennehen et al. (2012), which were also observed at approximately the same time of year, or from European biomass activities.

The Ca-rich particles observed strongly in case 6 are distinct and not observed to the same magnitude in the other flights, implying a unique source. It is possible that these are naturally occurring carbonate dusts; however, Umo et al. (2015) also measured several species of Ca-based dusts in their wood and bottom ash samples, suggesting that these could also be from biomass burning activities. The strong detection of Ca-rich particles alongside the K-dominant biomass particles supports this conclusion here. The relative prevalence of K-rich and Ca-rich particles found in the suband super-micron ranges mirrors the relationship observed in the biomass burning study by Andreae (1983). The large $\mathrm{Ca}$ signature is also observed in the silicate and mixed silicate spectra for this case (Fig. S2 in the Supplement), and consequently affects the $\mathrm{K} / \mathrm{Al}$ and $\mathrm{Ca} / \mathrm{Al}$ ratios (shown in Fig. 6). It is unclear whether these enhanced values are a result of internal mixing of silicates with the $\mathrm{Ca}$ - or K-rich biomass particles or if they are real feldspar signatures (as $\mathrm{K}$-feldspar or plagioclase). The $\mathrm{Fe} / \mathrm{Si}$ ratio is also elevated for this case and this could be due to increased detection of clay-like dusts or hematite, and/or internal mixing with anthropogenic smelting emissions.

\subsection{Sourcing the dust}

Unexpectedly, large fractions of silicate dusts are observed in every case. These filters were collected in March when the majority of the surrounding surface was snow covered; therefore, there is no obvious local source of mineral dust. Weinbruch et al. (2012) also identified large dust fractions in their samples collected at Ny-Ålesund in April 2008, and these dusts would likely act as a source of ice nucleating particles for clouds in this region. The presence of dust in such quantities could either be due to some local source, long-range transport or a combination of these two avenues. To better understand the characteristics of these dusts, the elemental ratios in Fig. 6 can be considered. In general, the consistency in the median $\mathrm{Si} / \mathrm{Al}$ ratio between each case suggests that the typical composition of the aluminosilicates has low variability, with each distribution skewed differently to account for the differences in the mean and variance values.

Elemental ratios can be used to infer a source of the mineral dusts. Several studies have investigated characteristic ratios of dusts from a variety of arid regions. For example, the African dust study by Formenti et al. (2008) calculated these ratios from airborne filter data and derived $\mathrm{Si} / \mathrm{Al}, \mathrm{K} / \mathrm{Al}$ and $\mathrm{Ca} / \mathrm{Al}$ ratios of approximately 3, 0.25 and 0.5 respectively. These values are within the limits of those calculated in this study (Fig. 6); however, a lack of good agreement suggests 
that these sources may not be related to the dusts analysed here. Zhang et al. (2001) presented these ratios for dusts collected at various Asian sites, and their Tibetan and Loess Plateau samples were found to have $\mathrm{Si} / \mathrm{Al}$ ratios of 4.6 and 2.5 respectively. The Loess values are consistent with the mean values obtained in all cases, whereas the Tibetan values lie within the upper bounds of samples 3 and 5. The Loess samples also had a $\mathrm{Ca} / \mathrm{Al}$ ratio of 2.7, lying between the median and mean values obtained for case 6 and within the upper bound of case 3; however, it is much greater than the average ratio derived for the majority of these cases. Their $\mathrm{K} / \mathrm{Al}$ ratio was found to be 0.95 , consistent with the first five cases but not case 6 . This could be due to the heightened $\mathrm{K}$ influence from biomass sources in case 6 , but could also be coincidental and care must be taken when attributing a transported dust sample to a given source via this method. The dust collected here does appear to have more in common with the Asian samples than the African samples; however, the composition of dusts originating from the same source region is not always consistent and can vary between close geographical locations (Glen and Brooks, 2013). It is also unclear how these ratios would be affected by transportation, as atmospheric processing would likely alter the composition of ageing dust with respect to the freshly emitted dust characteristics reported in these studies. Despite this, it is worth noting that Liu et al. (2015) identified high-altitude plumes during the springtime ACCACIA campaign, which hailed from the Asian continent. It could be possible that dusts from these sources were advected over large distances in addition to the black carbon explicitly measured and modelled by Liu et al. (2015). The increase in mean trajectory altitude with time, as shown in Fig. 3, supports this theory as the descent of air from $>1000 \mathrm{~m}$ could be drawing dusts down to the lowaltitudes considered. The theory that Asian dust contributes to the Arctic haze phenomenon is not new, and observations have indicated that this is the case (e.g. Rahn et al., 1977). However, models have not been able to produce conclusive evidence (Quinn et al., 2007). A key question in this hypothesis is theorising how the dust is lofted up to high altitudes in the atmosphere, and subsequently undergoes this long-range transportation, without experiencing cloud processing. It is possible that frontal uplifts at the source are responsible, with weakly scavenging mixed-phase clouds along the trajectories allowing the dust loading to remain so high.

\subsection{Mixed aerosol particles}

The degree of mixing in each case is different - as displayed by the variability in mean fractions shown in Fig. S2 in the Supplement - thus tying in with the differences between the air mass histories. Particles that have undergone long-range transport likely would have enhanced internal mixing and may not be adequately classified by the scheme employed here. Unclassified particles are prevalent in cases 3, 6 and 7 (Fig. 5). Variability within the categories (as seen in Fig. S2 in the Supplement) highlights the importance of treating the classifications with caution: they provide a good representation of the particle species collected, yet the ability of the criteria to account for mixed species is not always efficient.

The influence of unclassified particles on the population is most evident in the higher-altitude case: case 7 (Fig. 7) is distinctly different from its below-cloud counterpart (case 4, Fig. 5). In addition to the enhanced other fraction, large mixed chloride, sulfate and mixed silicate loadings are also identified above cloud (Fig. 7); classifications which could be attributed to anthropogenic influences. In this case, it is likely that these particles had undergone mixing over longrange transport. The contrast between the below- and abovecloud cases emphasises the segregation of the Arctic aerosol sources: whilst being influenced by local surface sources, the Arctic atmosphere is also affected by this influx of longrange transported aerosol particles - the Arctic haze - during the spring months (Barrie, 1986; Shaw, 1995; Liu et al., 2015). Both of these aerosol pathways will affect the cloud microphysics, and further investigation is required to better understand the importance of each. The particle classes detected in cases 4 and 7 could have interacted with the cloud layer as CCN or INPs, whilst the differences between them can be explained by the cloud restricting any direct mixing between the two populations.

The extent of internal and external mixing observed indicates that some INP predictions may be fraught with inaccuracy in this region; for example, DeMott et al. (2010) related INP concentration to the total aerosol concentration $>0.5 \mu \mathrm{m}$ under the assumption that most of these aerosol particles are INPs. However, efficient INPs (e.g. mineral dusts) were not found to be consistently dominant in this limit. As suggested by DeMott et al. (2010), this relation may not be applicable in cases heavily influenced by marine sources, and the high loadings of super-micron sea salt identified in some of the ACCACIA cases would qualify these as such. The use of dust-based parameterisations such as Niemand et al. (2012) or DeMott et al. (2015) may provide a more accurate prediction of the INP concentration in these cases.

Whilst it is likely that the dusts observed in this study would act as INPs, it cannot be determined how the unclassified and mixed particle categories would interact with the clouds in this region. In particular, the lack of sound quantitative $\mathrm{C}$ and $\mathrm{O}$ measurements prevents organic coatings from being identified; coatings which are important in interpreting aerosol-cloud interactions. The mixed particles identified here could likely act as $\mathrm{CCN}$ as they would possess a soluble component provided by the $\mathrm{Cl}$ or $\mathrm{S}$ signatures. However, it is also likely that they could influence the INP population; whilst soluble coatings may suppress ice nucleating ability, the presence of IN-active coatings and/or complex internal mixing could act to enhance it. Examples of IN-active coatings could include biological material, as some strains of bacteria have been observed to be efficient INPs in laboratory studies (Möhler et al., 2007; Hoose and Möhler, 2012). 
Some studies have identified cases where bacteria has survived long-range atmospheric transport by piggybacking dust particles (Yamaguchi et al., 2012). It is possible that such bacteria could influence the Arctic atmosphere via a similar transportation mechanism. Fundamentally, comprehending how these mixed particles interact and impact the cloud microphysics is a significant step to take towards improving our understanding of aerosol-cloud interactions in the Arctic springtime.

\section{Conclusions}

During the Aerosol-Cloud Coupling and Climate Interactions (ACCACIA) springtime campaign, in situ samples of Arctic aerosol particles were collected on polycarbonate filters. Analysis of these samples has been detailed, with a focus placed upon identifying the composition of the collected particles and investigating their potential sources. In total, six below-cloud exposures were analysed to infer how the local sources may influence the cloud microphysics of the region (Fig. 1) and one above-cloud case was considered to investigate the composition of transported particles (Fig. 7). The main findings of this study are as follows:

- Single-particle analysis of the filters produced number size distributions which were comparable (from approximately $0.5-10 \mu \mathrm{m})$ to those derived from the wingmounted optical particle counters (Fig. 4). Better agreement between these distributions was achieved in lower RH sampling conditions. The composition of the particles collected was strongly dependent upon size across all samples, with crustal minerals and sea salts dominating the super-micron range. Carbon- and sulfur-based particles were mostly observed in the $<1 \mu \mathrm{m}$ limit (Fig. 5). Large fractions of mixed particles - as shown by the other, mixed silicate and mixed chloride categories in Figs. 5 and 7 -were identified in each case. The impact of these particles on cloud microphysics as potential INPs and/or CCN is not quantifiable by this study.

- Distinct size-dependent compositional trends were observed in each sample, with stark differences between cases (Fig. 5). These differences were attributed to variations in the air mass histories; cases 1 and 2 presented a silicate dust dominance, whilst cases 4 and 5 had similar chloride and silicate loadings. These similarities were mirrored by their closely related source regions (Fig. 3). The relationship between composition and trajectory was strengthened by the unique attributes of case 6; both the trends and trajectory were distinct in this case and the particle classifications identified can be explained by hypothesised sources along the trajectory presented.
- Crustal minerals were identified in all cases, despite the seasonal local snow cover. The HYSPLIT back trajectories (Fig. 3) were variable in direction, yet typically increased in mean altitude over time. These dusts were therefore hypothesised to have undergone long-range, high-altitude transport from distant sources, through regions containing weakly scavenging mixedphase clouds. Some elemental characteristics (Fig. 6) were found to be consistent with Asian dust sources; however, it is not known how long-range transport may affect the composition of these dusts and so this theory cannot be proven with these data.

The non-volatile, coarse-mode Arctic aerosol particles analysed by this study showed great variation between subsequent days and different meteorological conditions; therefore, it would be difficult to incorporate these findings into models. However, the measurements from the springtime ACCACIA campaign provide a good opportunity to simultaneously investigate both the properties of aerosol particles in the region and the microphysical characteristics of the clouds observed. Further study of the cloud microphysics of these cases, with reference to these aerosol observations, will allow us to improve both our understanding and the representation of aerosol-cloud interactions in climate models and act to reduce the uncertainty in forecasting the Arctic atmosphere in the future.

\section{The Supplement related to this article is available online at doi:10.5194/acp-16-4063-2016-supplement.}

\begin{abstract}
Acknowledgements. This work was funded by the National Environment Research Council (NERC), under grant NE/I028696/1, as part of the ACCACIA campaign. G. Young was supported by a NERC PhD studentship. We would like to thank the ACCACIA project team for their efforts, and J. Crosier and N. Marsden for their helpful comments and advice. Airborne data were obtained using the BAe-146-301 Atmospheric Research Aircraft (ARA) flown by Directflight Ltd and managed by the Facility for Airborne Atmospheric Measurements (FAAM), which is a joint entity of the Natural Environment Research Council (NERC) and the Met Office. G. Young would also like to thank J. Fellowes and J. Waters at the Williamson Research Centre for their guidance with the ESEM instrument and the European Geosciences Union for funding the publication this article as part of an OSP 2015 award.
\end{abstract}

Edited by: W. T. Sturges

\section{References}

Andreae, M. O.: Soot Carbon and Excess Fine Potassium: LongRange Transport of Combustion-Derived Aerosols, Science, 220, 1148-1151, doi:10.1126/science.220.4602.1148, 1983. 
Andreae, M. O. and Rosenfeld, D.: Aerosol cloud precipitation interactions. Part 1. The nature and sources of cloud-active aerosols, Earth Sci. Rev., 89, 13-41, doi:10.1016/j.earscirev.2008.03.001, 2008.

Andreae, M. O., Elbert, W., Gabriel, R., Johnson, D. W., Osborne, S., and Wood, R.: Soluble ion chemistry of the atmospheric aerosol and $\mathrm{SO}_{2}$ concentrations over the eastern North Atlantic during ACE-2, Tellus B, 52, 1066-1087, doi:10.1034/j.16000889.2000.00105.x, 2000.

Barrie, L. A.: Arctic Air Chemistry: An Overview, in: Arctic Air Pollution, edited by: Stonehouse, B., Cambridge University Press, Cambridge, UK, 1986.

Behrenfeldt, U., Krejci, R., Ström, J., and Stohl, A.: Chemical properties of Arctic aerosol particles collected at the Zeppelin station during the aerosol transition period in May and June of 2004, Tellus B, 60, 405-415, doi:10.1111/j.1600-0889.2008.00349.x, 2008.

Boucher, O., Randall, D., Artaxo, P., Bretherton, C., Feingold, G., Forster, P., Kerminen, V. M., Kondo, Y., Liao, H., Lohmann, U., Rasch, P., Satheesh, S. K., Sherwood, S., Stevens, B., and Zhang, X. Y.: Clouds and Aerosols, in: Climate Change 2013: The Physical Science Basis. Contribution of Working Group I to the Fifth Assessment Report of the Intergovernmental Panel on Climate Change, edited by: Stocker, T. F., Qin, D., Plattner, G. K., Tignor, M., Allen, S. K., Boschung, J., Nauels, A., Xia, Y., Bex, V., and Midgley, P. M., Cambridge University Press, Cambridge, United Kingdom, New York, NY, USA, 2013.

Chou, C., Formenti, P., Maille, M., Ausset, P., Helas, G., Harrison, M., and Osborne, S.: Size distribution, shape, and composition of mineral dust aerosols collected during the African Monsoon Multidisciplinary Analysis Special Observation Period 0: Dust and Biomass-Burning Experiment field campaign in Niger, January 2006, J. Geophys. Res., 113, D00C10, doi:10.1029/2008JD009897, 2008.

Connolly, P. J., Möhler, O., Field, P. R., Saathoff, H., Burgess, R., Choularton, T., and Gallagher, M.: Studies of heterogeneous freezing by three different desert dust samples, Atmos. Chem. Phys., 9, 2805-2824, doi:10.5194/acp-9-2805-2009, 2009.

Conny, J. M. and Norris, G. A.: Scanning Electron Microanalysis and Analytical Challenges of Mapping Elements in Urban Atmospheric Particles, Environ. Sci. Technol., 45, 7380-7386, doi:10.1021/es2009049, 2011.

Crosier, J., Allan, J. D., Coe, H., Bower, K. N., Formenti, P., and Williams, P. I.: Chemical composition of summertime aerosol in the Po Valley (Italy), northern Adriatic and Black Sea, Q. J. Roy. Meteor. Soc., 133, 61-75, doi:10.1002/qj.88, 2007.

Curry, J. A., Rossow, W. B., Randall, D., and Schramm, J. L.: Overview of Arctic Cloud and Radiation Characteristics, J. Climate, 9, 1731-1764, doi:10.1175/15200442(1996)009<1731:OOACAR>2.0.CO;2, 1996.

de Boer, G., Shupe, M. D., Caldwell, P. M., Bauer, S. E., Persson, O., Boyle, J. S., Kelley, M., Klein, S. A., and Tjernström, M.: Near-surface meteorology during the Arctic Summer Cloud Ocean Study (ASCOS): evaluation of reanalyses and global climate models, Atmos. Chem. Phys., 14, 427-445, doi:10.5194/acp-14-427-2014, 2014.

DeMott, P. J., Prenni, A. J., Liu, X., Kreidenweis, S. M., Petters, M. D., Twohy, C. H., Richardson, M. S., Eidhammer, T., and Rogers, D. C.: Predicting global atmospheric ice nuclei distribu- tions and their impacts on climate, P. Natl. Acad. Sci. USA, 107, 11217-11222, doi:10.1073/pnas.0910818107, 2010.

DeMott, P. J., Prenni, A. J., McMeeking, G. R., Sullivan, R. C., Petters, M. D., Tobo, Y., Niemand, M., Möhler, O., Snider, J. R., Wang, Z., and Kreidenweis, S. M.: Integrating laboratory and field data to quantify the immersion freezing ice nucleation activity of mineral dust particles, Atmos. Chem. Phys., 15, 393-409, doi:10.5194/acp-15-393-2015, 2015.

Draxler, R. R. and Hess, G. D.: An Overview of the HYSPLIT_4 Modelling System for Trajectories, Dispersion, and Deposition, Aust. Meteorol. Mag., 47, 295-308, 1998.

Fleming, Z. L., Monks, P. S., and Manning, A. J.: Review: Untangling the influence of air-mass history in interpreting observed atmospheric composition, Atmos. Res., 104, 1-39, doi:10.1016/j.atmosres.2011.09.009, 2012.

Formenti, P., Elbert, W., Maenhaut, W., Haywood, J., Osborne, S., and Andreae, M. O.: Inorganic and carbonaceous aerosols during the Southern African Regional Science Initiative (SAFARI 2000) experiment: Chemical characteristics, physical properties, and emission data for smoke from African biomass burning, J. Geophys. Res., 108, 8488, doi:10.1029/2002JD002408, 2003.

Formenti, P., Rajot, J. L., Desboeufs, K., Caquineau, S., Chevaillier, S., Nava, S., Gaudichet, A., Journet, E., Triquet, S., Alfaro, S., Chiari, M., Haywood, J., Coe, H., and Highwood, E.: Regional variability of the composition of mineral dust from western Africa: Results from the AMMA SOP0/DABEX and DODO field campaigns, J. Geophys. Res., 113, D00C13, doi:10.1029/2008JD009903, 2008.

Formenti, P., Schütz, L., Balkanski, Y., Desboeufs, K., Ebert, M., Kandler, K., Petzold, A., Scheuvens, D., Weinbruch, S., and Zhang, D.: Recent progress in understanding physical and chemical properties of African and Asian mineral dust, Atmos. Chem. Phys., 11, 8231-8256, doi:10.5194/acp-11-8231-2011, 2011.

Geng, H., Ryu, J., Jung, H.-J., Chung, H., Ahn, K.-H., and Ro, C.-U.: Single-Particle Characterization of Summertime Arctic Aerosols Collected at Ny-Ålesund, Svalbard, Environ. Sci. Technol., 44, 2348-2353, doi:10.1021/es903268j, 2010.

Glen, A. and Brooks, S. D.: A new method for measuring optical scattering properties of atmospherically relevant dusts using the Cloud and Aerosol Spectrometer with Polarization (CASPOL), Atmos. Chem. Phys., 13, 1345-1356, doi:10.5194/acp-13-13452013, 2013.

Hand, V. L., Capes, G., Vaughan, D. J., Formenti, P., Haywood, J. M., and Coe, H.: Evidence of internal mixing of African dust and biomass burning particles by individual particle analysis using electron beam techniques, J. Geophys. Res., 115, D13301, doi:10.1029/2009JD012938, 2010.

Hara, K., Yamagata, S., Yamanouchi, T., Sato, K., Herber, A., Iwasaka, Y., Nagatani, M., and Nakata, H.: Mixing states of individual aerosol particles in spring Arctic troposphere during ASTAR 2000 campaign, J. Geophys. Res., 108, 4209, doi:10.1029/2002JD002513, 2003.

Heintzenberg, J., Hansson, H.-C., Ogren, J. A., Covert, D. S., and Blanchet, J.-P.: Physical and Chemical Properties of Arctic Aerosols and Clouds, in: Arctic Air Pollution, edited by: Stonehouse, B., Cambridge University Press, Cambridge, UK, 1986.

Hoose, C. and Möhler, O.: Heterogeneous ice nucleation on atmospheric aerosols: a review of results from laboratory experiments, 
Atmos. Chem. Phys., 12, 9817-9854, doi:10.5194/acp-12-98172012, 2012.

Jackson, R. C., McFarquhar, G. M., Korolev, A. V., Earle, M. E., Liu, P. S. K., Lawson, R. P., Brooks, S., Wolde, M., Laskin, A., and Freer, M.: The dependence of ice microphysics on aerosol concentration in arctic mixed-phase stratus clouds during ISDAC and M-PACE, J. Geophys. Res., 117, D15207, doi:10.1029/2012JD017668, 2012.

John, W., Hering, S., Reischl, G., Sasaki, G., and Goren, S.: Characteristics of Nuclepore filters with large pore size - II. Filtration properties, Atmos. Environ., 17, 373-382, doi:10.1016/00046981(83)90054-9, 1983

Johnson, B., Turnbull, K., Brown, P., Burgess, R., Dorsey, J., Baran, A. J., Webster, H., Haywood, J., Cotton, R., Ulanowski, Z., Hesse, E., Woolley, A., and Rosenberg, P.: In situ observations of volcanic ash clouds from the FAAM aircraft during the eruption of Eyjafjallajökull in 2010, J. Geophys. Res., 117, D00U24, doi:10.1029/2011JD016760, 2012.

Kandler, K., Benker, N., Bundke, U., Cuevas, E., Ebert, M., Knippertz, P., Rodríguez, S., Schütz, L., and Weinbruch, S.: Chemical composition and complex refractive index of Saharan Mineral Dust at Izaña, Tenerife (Spain) derived by electron microscopy, Atmos. Environ., 41, 8058-8074, doi:10.1016/j.atmosenv.2007.06.047, 2007.

Kandler, K., Lieke, K., Benker, N., Emmel, C., Küpper, M., MüllerEbert, D., Ebert, M., Scheuvens, D., Schladitz, A., Schütz, L., and Weinbruch, S.: Electron microscopy of particles collected at Praia, Cape Verde, during the Saharan Mineral Dust Experiment: particle chemistry, shape, mixing state and complex refractive index, Tellus B, 63, 475-496, doi:10.1111/j.16000889.2011.00550.x, 2011.

Kanji, Z. A., Welti, A., Chou, C., Stetzer, O., and Lohmann, U.: Laboratory studies of immersion and deposition mode ice nucleation of ozone aged mineral dust particles, Atmos. Chem. Phys., 13, 9097-9118, doi:10.5194/acp-13-9097-2013, 2013.

Krejci, R., Ström, J., de Reus, M., and Sahle, W.: Single particle analysis of the accumulation mode aerosol over the northeast Amazonian tropical rain forest, Surinam, South America, Atmos. Chem. Phys., 5, 3331-3344, doi:10.5194/acp-5-3331-2005, 2005.

Krueger, B. J., Grassian, V. H., Laskin, A., and Cowin, J. P.: The transformation of solid atmospheric particles into liquid droplets through heterogeneous chemistry: Laboratory insights into the processing of calcium containing mineral dust aerosol in the troposphere, Geophys. Res. Lett., 30, 1148, doi:10.1029/2002GL016563, 2003.

Lance, S., Brock, C. A., Rogers, D., and Gordon, J. A.: Water droplet calibration of the Cloud Droplet Probe (CDP) and inflight performance in liquid, ice and mixed-phase clouds during ARCPAC, Atmos. Meas. Tech., 3, 1683-1706, doi:10.5194/amt3-1683-2010, 2010.

Levin, Z., Ganor, E., and Gladstein, V.: The Effects of Desert Particles Coated with Sulfate on Rain Formation in the Eastern Mediterranean, J. Appl. Meteorol., 35, 1511-1523, doi:10.1175/1520-0450(1996)035<1511:TEODPC>2.0.CO;2, 1996.

Levin, Z., Teller, A., Ganor, E., and Yin, Y.: On the interactions of mineral dust, sea-salt particles, and clouds: A measurement and modeling study from the Mediterranean Israeli
Dust Experiment campaign, J. Geophys. Res., 110, D20202, doi:10.1029/2005JD005810, 2005.

Li, J., Pósfai, M., Hobbs, P. V., and Buseck, P. R.: Individual aerosol particles from biomass burning in southern Africa: 2. Compositions and aging of inorganic particles, J. Geophys. Res., 108, 8484, doi:10.1029/2002JD002310, 2003.

Liu, B. Y. H. and Lee, K. W.: Efficiency of membrane and nuclepore filters for submicrometer aerosols, Environ. Sci. Technol., 10, 345-350, doi:10.1021/es60115a002, 1976.

Liu, D., Quennehen, B., Darbyshire, E., Allan, J. D., Williams, P. I., Taylor, J. W., Bauguitte, S. J.-B., Flynn, M. J., Lowe, D., Gallagher, M. W., Bower, K. N., Choularton, T. W., and Coe, H.: The importance of Asia as a source of black carbon to the European Arctic during springtime 2013, Atmos. Chem. Phys., 15, 11537-11555, doi:10.5194/acp-15-11537-2015, 2015.

Lloyd, G., Choularton, T. W., Bower, K. N., Crosier, J., Jones, H., Dorsey, J. R., Gallagher, M. W., Connolly, P., Kirchgaessner, A. C. R., and Lachlan-Cope, T.: Observations and comparisons of cloud microphysical properties in spring and summertime Arctic stratocumulus clouds during the ACCACIA campaign, Atmos. Chem. Phys., 15, 3719-3737, doi:10.5194/acp-15-37192015, 2015.

Mamane, Y. and Noll, K. E.: Characterization of large particles at a rural site in the eastern United States: Mass distribution and individual particle analysis, Atmos. Environ., 19, 611-622, doi:10.1016/0004-6981(85)90040-X, 1985.

Möhler, O., DeMott, P. J., Vali, G., and Levin, Z.: Microbiology and atmospheric processes: the role of biological particles in cloud physics, Biogeosciences, 4, 1059-1071, doi:10.5194/bg-4-10592007, 2007.

Möhler, O., Benz, S., Saathoff, H., Schnaiter, M., Wagner, R., Schneider, J., Walter, S., Ebert, V., and Wagner, S.: The effect of organic coating on the heterogeneous ice nucleation efficiency of mineral dust aerosols, Environ. Res. Lett., 3, 025007 doi:10.1088/1748-9326/3/2/025007, 2008.

Murray, B. J., O’Sullivan, D., Atkinson, J. D., and Webb, M. E.: Ice nucleation by particles immersed in supercooled cloud droplets, Chem. Soc. Rev., 41, 6519-6554, doi:10.1039/c2cs35200a, 2012.

Niemand, M., Möhler, O., Vogel, B., Vogel, H., Hoose, C., Connolly, P., Klein, H., Bingemer, H., DeMott, P., Skrotzki, J., and Leisner, T.: A Particle-Surface-Area-Based Parameterization of Immersion Freezing on Desert Dust Particles, J. Atmos. Sci., 69, 3077-3092, doi:10.1175/JAS-D-11-0249.1, 2012.

Perovich, D. K., Richter-Menge, J. A., Jones, K. F., and Light, B.: Sunlight, water, and ice: Extreme Arctic sea ice melt during the summer of 2007, Geophys. Res. Lett., 35, L11501, doi:10.1029/2008GL034007, 2008.

Pruppacher, H. R. and Klett, J. D.: Microphysics of Clouds and Precipitation, 2nd Edn., Kluwer Academic Publishers, Dordrecht, the Netherlands, 1997.

Quennehen, B., Schwarzenboeck, A., Matsuki, A., Burkhart, J. F., Stohl, A., Ancellet, G., and Law, K. S.: Anthropogenic and forest fire pollution aerosol transported to the Arctic: observations from the POLARCAT-France spring campaign, Atmos. Chem. Phys., 12, 6437-6454, doi:10.5194/acp-12-6437-2012, 2012.

Quinn, P. K., Shaw, G., Andrews, E., Dutton, E. G., RuohoAirola, T., and Gong, S. L.: Arctic haze: current trends and 
knowledge gaps, Tellus B, 59, 99-114, doi:10.1111/j.16000889.2006.00238.x, 2007.

Rahn, K. A.: Relative importances of North America and Eurasia as sources of Arctic aerosol, Atmos. Environ., 15, 1447-1455, doi:10.1016/0004-6981(81)90351-6, 1981.

Rahn, K. A., Borys, R. D., and Shaw, G. E.: The Asian source of Arctic haze bands, Nature, 268, 713-715, doi:10.1038/268713a0, 1977.

Reimann, C., Banks, D., and Caritat, P. de: Impacts of Airborne Contamination on Regional Soil and Water Quality: The Kola Peninsula, Russia, Environ. Sci. Technol., 34, 2727-2732, doi:10.1021/es9912933, 2000.

Rosenberg, P. D., Dean, A. R., Williams, P. I., Dorsey, J. R., Minikin, A., Pickering, M. A., and Petzold, A.: Particle sizing calibration with refractive index correction for light scattering optical particle counters and impacts upon PCASP and CDP data collected during the Fennec campaign, Atmos. Meas. Tech., 5, 1147-1163, doi:10.5194/amt-5-1147-2012, 2012.

Seiler, W. and Crutzen, P.: Estimates of gross and net fluxes of carbon between the biosphere and the atmosphere from biomass burning, Climatic Change, 2, 207-247, doi:10.1007/BF00137988, 1980.

Serreze, M. C., Holland, M. M., and Stroeve, J.: Perspectives on the Arctic's Shrinking Sea-Ice Cover, Science, 315, 1533-1536, doi:10.1126/science.1139426, 2007.

Shaw, G. E.: The Arctic Haze Phenomenon, B. Am. Meteorol. Soc., 76, 2403-2414, doi:10.1175/15200477(1995)076<2403:TAHP>2.0.CO;2, 1995.

Steinnes, E., Lukina, N., Nikonov, V., Aamlid, D., and Røyset, O.: A Gradient Study of 34 Elements in the Vicinity of a CopperNickel Smelter in the Kola Peninsula, Environ. Monit. Assess., 60, 71-88, doi:10.1023/A:1006165031985, 2000.

Ström, J., Umegård, J., Tørseth, K., Tunved, P., Hansson, H.C., Holmén, K., Wismann, V., Herber, A., and König-Langlo, G.: One year of particle size distribution and aerosol chemical composition measurements at the Zeppelin Station, Svalbard, March 2000-March 2001, Phys. Chem. Earth, 28, 1181-1190, doi:10.1016/j.pce.2003.08.058, 2003.

Trembath, J. A.: Airborne CCN Measurements, PhD thesis, University of Manchester, Manchester, 2013.

Tunved, P., Ström, J., and Krejci, R.: Arctic aerosol life cycle: linking aerosol size distributions observed between 2000 and 2010 with air mass transport and precipitation at Zeppelin station, Ny-Ålesund, Svalbard, Atmos. Chem. Phys., 13, 3643-3660, doi:10.5194/acp-13-3643-2013, 2013.
Umo, N. S., Murray, B. J., Baeza-Romero, M. T., Jones, J. M., LeaLangton, A. R., Malkin, T. L., O'Sullivan, D., Neve, L., Plane, J. M. C., and Williams, A.: Ice nucleation by combustion ash particles at conditions relevant to mixed-phase clouds, Atmos. Chem. Phys., 15, 5195-5210, doi:10.5194/acp-15-5195-2015, 2015.

Verlinde, J. Y., Harrington, J. Y., McFarquhar, G. M., Yannuzzi, V. T., Avramov, A., Greenberg, S., Johnson, N., Zhang, G., Poellot, M. R., Mather, J. H., Turner, D. D., Eloranta, E. W., Zak, B. D., Prenni, A. J., Daniel, J. S., Kok, G. L., Tobin, D. C., Holz, R., Sassen, K., Spangenberg, D., Minnis, P., Tooman, T. P., Ivey, M. D., Richardson, S. J., Bahrmann, C. P., Shupe, M., Demott, P. J., Heymsfield, A. J., and Schofield, R.: The Mixed-Phase Arctic Cloud Experiment, B. Am. Meteorol. Soc., 88, 205-221, doi:10.1175/BAMS-88-2-205, 2007.

Vihma, T., Pirazzini, R., Fer, I., Renfrew, I. A., Sedlar, J., Tjernström, M., Lüpkes, C., Nygård, T., Notz, D., Weiss, J., Marsan, D., Cheng, B., Birnbaum, G., Gerland, S., Chechin, D., and Gascard, J. C.: Advances in understanding and parameterization of small-scale physical processes in the marine Arctic climate system: a review, Atmos. Chem. Phys., 14, 9403-9450, doi:10.5194/acp-14-9403-2014, 2014.

Weinbruch, S., Wiesemann, D., Ebert, M., Schütze, K., Kallenborn, R., and Ström, J.: Chemical composition and sources of aerosol particles at Zeppelin Mountain (Ny Ålesund, Svalbard): An electron microscopy study, Atmos. Environ., 49, 142-150, doi:10.1016/j.atmosenv.2011.12.008, 2012.

Yakobi-Hancock, J. D., Ladino, L. A., and Abbatt, J. P. D.: Feldspar minerals as efficient deposition ice nuclei, Atmos. Chem. Phys., 13, 11175-11185, doi:10.5194/acp-13-11175-2013, 2013.

Yamaguchi, N., Ichijo, T., Sakotani, A., Baba, T., and Nasu, M.: Global dispersion of bacterial cells on Asian dust, Scientific Reports, 2, 525, doi:10.1038/srep00525, 2012.

Zhang, X. Y., Arimoto, R., Cao, J. J., An, Z. S., and Wang, D.: Atmospheric dust aerosol over the Tibetan Plateau, J. Geophys. Res., 106, 18471-18476, doi:10.1029/2000JD900672, 2001.

Zhao, C., Klein, S. A., Xie, S., Liu, X., Boyle, J. S., and Zhang, Y.: Aerosol first indirect effects on non-precipitating low-level liquid cloud properties as simulated by CAM5 at ARM sites, Geophys. Res. Lett., 39, L08806, doi:10.1029/2012GL051213, 2012.

Zimmermann, F., Weinbruch, S., Schütz, L., Hofmann, H., Ebert, M., Kandler, K., and Worringen, A.: Ice nucleation properties of the most abundant mineral dust phases, J. Geophys. Res., 113, D23204, doi:10.1029/2008JD010655, 2008. 